\title{
The occurence of black spot disease in Astyanax aff. fasciatus (characiformes: characidae) in the Guaíba Lake basin, RS, Brazil
}

\author{
Flores-Lopes, Fi,b* \\ a'Laboratório de Ictiologia, Programa de Pós-Graduação em Biologia Animal, Departamento de Zoologia, \\ Instituto de Biociências - IB, Universidade Federal do Rio Grande do Sul - UFRGS, Av Bento Gonçalves, \\ 9500, bloco IV, prédio 43.435, CEP 90540-000, Porto Alegre, RS, Brazil \\ ${ }^{\text {b}}$ Departamento de Ciências Biológicas, Universidade Estadual de Santa Cruz - UESC, Rodovia Jorge Amado,BA-415, \\ km 16, CEP 45662-900, Ilhéus, BA, Brazil \\ *e-mail: fabiologo5@hotmail.com
}

Received: June 4, 2012 - Accepted: June 4, 2013 - Distributed: November 30, 2014

(With 2 figures)

\begin{abstract}
Black spot disease is common in freshwater fish and is usually caused by the metacercaria stage of digenetic trematodes, normally from the Diplostomidae family. The present study evaluated the prevalence and intensity of this disease in Astyanax aff. fasciatus (Teleostei: Characiformes) in the Guaíba Lake basin (RS, Brazil), including body parts assessment and the points of sampling with higher occurrence of black spots. Fish samples were taken seasonally from December 2002 until October 2004. The samples were collected with the use of a seine net at eleven points. The specimens were fixed in $10 \%$ formalin and stored in $70 \%$ ethanol. Black spot disease showed a low frequency in the Guaíba lake basin (2.07\%) and no specificity to the species Astyanax aff. fasciatus was observed. A high prevalence among the individuals and high intensity of infection levels was found in the ventral and dorsal regions in relation to other body parts (e.g., pectoral, pelvic and anal regions). Among the sampling points studied, we observed a higher prevalence on samples collected at points Gasômetro, Saco da Alemoa and Sinos, located in open areas with less occurrence of mollusks.
\end{abstract}

Keywords: prevalence, infection, parasites.

\section{Ocorrência da doença dos pontos pretos em Astyanax aff. fasciatus (characiformes: characidae) na bacia do lago Guaíba, RS, Brazil}

\begin{abstract}
Resumo
A doença dos pontos pretos é comum em peixes de água doce, sendo provocada por metacercárias de trematódeos digenéticos, normalmente da família Diplostomidae. Este estudo avaliou a prevalência desta doença em Astyanax aff. fasciatus (Teleostei: Characiformes) da bacia hidrográfica do lago Guaíba (RS) e avaliou as regiões do corpo e pontos de amostragem de maior ocorrência. As amostragens foram realizadas sazonalmente de dezembro de 2002 até outubro de 2004 e os exemplares coletados com redes de arrasto do tipo picaré em onze pontos da bacia estudada. Os peixes foram fixados em formaldeído a $10 \%$ e conservados em etanol $70 \%$. A doença dos pontos pretos demonstrou baixa freqüência para as amostras coletadas na bacia hidrográfica do lago Guaíba $(2,07 \%)$ e não foi verificada especificidade com a espécie $A$. fasciatus. Maior prevalência e intensidade de infecção ocorreram nas regiões ventral e dorsal em relação às outras partes do corpo (ex: regiões peitoral, pélvica e anal). Entre os pontos estudados, foi observado elevada prevalência nas amostras coletadas nos pontos Gasômetro, Saco da Alemoa e Sinos, localizados em áreas mais abertas e com menor ocorrência de moluscos.
\end{abstract}

Palavras-chave: prevalência, infecção, parasito.

\section{Introduction}

Black spot disease is common in freshwater fish (Post, 1987) and its occurrence has been reported in several species of a variety of taxonomic groups and ecological niches (Hoffman, 1967). The disease is usually caused by the metacercaria stage of several species from different digenetic trematodes genres and families (usually Diplostomidae) (Overstreet et al., 2002).
The parasite penetrates through the skin of the fish, becoming an encysted metacercaria (Lane and Morris, 2000) and in response the host encapsulates the parasite in a fibrous capsule. The disease is characterised by the migration of melanocytes through the cysts' fibrous wall (Bush et al., 2001), causing the characteristic appearance of black spots. 
The infection occurs when the cercariae penetrate the fish's body surface, forming encysted metacercaria that then enter the definitive host, birds, upon ingestion (Steedman, 1991). The life cycle of these trematodes is complex, involving a series of at least 3 hosts, thus several fish serve as intermediate host in the development of the parasite. Usually the adult parasites are located in the piscivorous bird's intestine (Overstreet et al., 2002).

Understanding the prevalence and potential effect of parasites in fish can be important in explaining the patterns associated with the dynamics of fish populations and community structure (Quist et al., 2007). Such effects and patterns have been studied in individuals (Ryce et al., 2004), populations (Gilbert and Granath, 2003) and communities (Steedman, 1991). Several researchers have associated black spot disease with growth retardation, weight loss and to the high mortality of young infected fish, which could be a regulatory factor in the host population (Lemly and Esch, 1985). However, Teixeira-de-Mello and Eguren (2008) observed that the prevalence of black spot disease in Astyanax aff. fasciatus (Cuvier, 1819) does not show significant seasonal changes during the sampling period and observed a neutral effect of this parasite, whereby Phoxinus phoxinus fish (Linnaeus, 1758) infected with digenean larvae had increased growth and no host damage.

In Guaíba Lake, Southern Brazil, few studies have been conducted to evaluate parasitic infections in fish. The only published study on black spot disease in this locate is by Flores-Lopes and Thomaz (2011), who evaluated environmental quality by analysing the frequency of the disease. Additionally, Amato et al. (2001) studied Diplostomidae larvae in Loricariichthys anus (Valenciennes, 1835) and Monteiro et al. (2007) studied three species of digenetic that occur in aquatic birds in this area.

The current study aimed to evaluate the prevalence and intensity of black spot disease in Astyanax aff. fasciatus in the Guaíba Lake basin, RS, and to determine the infection intensity among the regions of the body and the sampling points.

\section{Material and Methods}

Guaíba Lake is one of the most important water resources of the state of Rio Grande do Sul (Malabarba et al., 2004). The water body lies on a SE-NW axis, being about $50 \mathrm{~km}$ $\times 12 \mathrm{~km}$ with an area of about $500 \mathrm{~km}^{2}$ and depths ranging from 5 to 6 metres (Malabarba et al., 2004). Lake Guaíba basin covers the most populous area with the largest concentration of economic activities in the state of Rio Grande do Sul. There are 5.9 million inhabitants $(56 \%$ of the state population), spread over 251 municipalities (54\% of cities). Guaíba Lake supplies the major city of Porto Alegre and neighbouring municipalities, reaching $1,500,000$ inhabitants. Due to the high human concentration and industries, the lake receives a large amount of domestic and industrial waste from several origins, directly or through its main tributaries (Gravataí, Sinos and Caí Rivers) (FEPAM, 1992).
Guaíba lake basin drains an area of $85,950 \mathrm{~km}^{2}$ and consists of eight sub-basins, with direct discharges from rivers Vacacaí-Jacuí contributing the greatest volume of water $(84.6 \%)$, followed by Caí River, Sinos River, Gravataí River and several streams, with $15.4 \%$ of the water volume (Vieira and Rangel, 1988). The lake bed and basin therefore accumulate waste from various activities of the human population in the basin (Dalto and Meneghetti, 1998).

Fish samples were taken seasonally from December 2002 until October 2004. Data were analysed in two separate periods of one year each: December 2002 to December 2003 and January to December 2004.

The samples were collected with the use of a seine net $(15 \mathrm{~m} \times 1.5 \mathrm{~m}$; mesh size $0.5 \mathrm{~cm})$ (Malabarba and Reis, 1987), at eleven locations. Six were in Guaíba Lake (Pt.1 - Gasômetro, Porto Alegre municipality $\left(30^{\circ} 02^{\prime}\right.$ 06.3" S and 51 $14^{\prime}$ '29.3" W); Pt.2 - Saco da Alemoa, Eldorado do Sul municipality (29 59' $15.6^{\prime \prime} \mathrm{S}$ and $\left.51^{\circ} 14^{\prime} 24.1^{\prime \prime} \mathrm{W}\right)$; Pt.3 - Foz do Celupa, Guaíba municipality (30 $06^{\circ}$ ' $10^{\prime \prime}$ S and $\left.51^{\circ} 18^{\prime} 42.4^{\prime \prime} \mathrm{W}\right)$; Pt.4 - Praia da Alegria, Guaíba municipality $\left(30^{\circ} 08^{\prime} 28.7^{\prime \prime} \mathrm{S}\right.$ and $51^{\circ} 18^{\prime} 53.4$ ' W); Pt.5 - Barra do Ribeiro, Barra do Ribeiro municipality (30 17' 11.4" S and 51 ${ }^{\circ} 18^{\prime} 01^{\prime}$ ' W), and Pt.6 - Praia de Ipanema, Porto Alegre municipality $\left(30^{\circ} 08^{\prime} 03\right.$ ' $\mathrm{S}$ and $\left.51^{\circ} 14^{\prime} 07^{\prime} \mathrm{W}\right)$ ) and five locations on three tributary rivers. Among these five locations, two were on the Caí River (Pt.7 - at the bridge and BR 386 highway (29 49' 22.6"' $\mathrm{S}$ and $\left.51^{\circ} 21^{\prime} 00^{\prime} \mathrm{W}\right)$; and Pt.8 - Morretes locality, next to the mouth of the Jacuí River (29 $55^{\prime} 43.9^{\prime \prime} \mathrm{S}$ and $51^{\circ}$ 17 ' 13.8” W), both in Nova Santa Rita municipality), one at Sinos River (Pt.9 - at the bridge and BR 386 highway (29 52'36.5' S and 51 '14'35.4' W)), two on Gravataí River (Pt.10 - near RS 118 highway (29 57' 43.7'’ S and 51 00' 09' W), and Pt.11 - Passo das Canoas (29 57 ' 25.7' $\mathrm{S}$ and $51^{\circ} 00^{\prime} 23.2$ ' $\left.\mathrm{W}\right)$, both in the Gravataí municipality) (Figure 1).

At each location, a seine net was used 4 times near the shore. Collected specimens were fixed in $10 \%$ formalin. In the laboratory, the material was sorted, identified to the species level according to Malabarba (1989) and preserved in $70 \%$ ethanol. Part of the analysed material was deposited in the scientific collection of the Federal University of Rio Grande do Sul (UFRGS). Specimens infected by digenetic disease-causing black spots (probably of the Diplostomidae family) were separated for analysis.

For identification, some parasites were removed and fixed with or without compression in AFA (alcohol 93\%, formalin 5\%, acetic acid 2\%), stained in alcoholic-acid carmine, dehydrated in an alcohol series, cleared in methyl salicylate and mounted in Canada balsam. Measurements are in micrometres unless otherwise stated, with the mean in parentheses followed by the number of specimens measured in brackets, where applicable. Representative type-specimens were deposited in the Helminthological Collection of the Oswaldo Cruz Institute (CHIOC), Rio de Janeiro, Brazil. The identification was carried out by specialists of the Laboratory of Parasitology, Federal University of Rio Grande do Sul (UFRGS). 


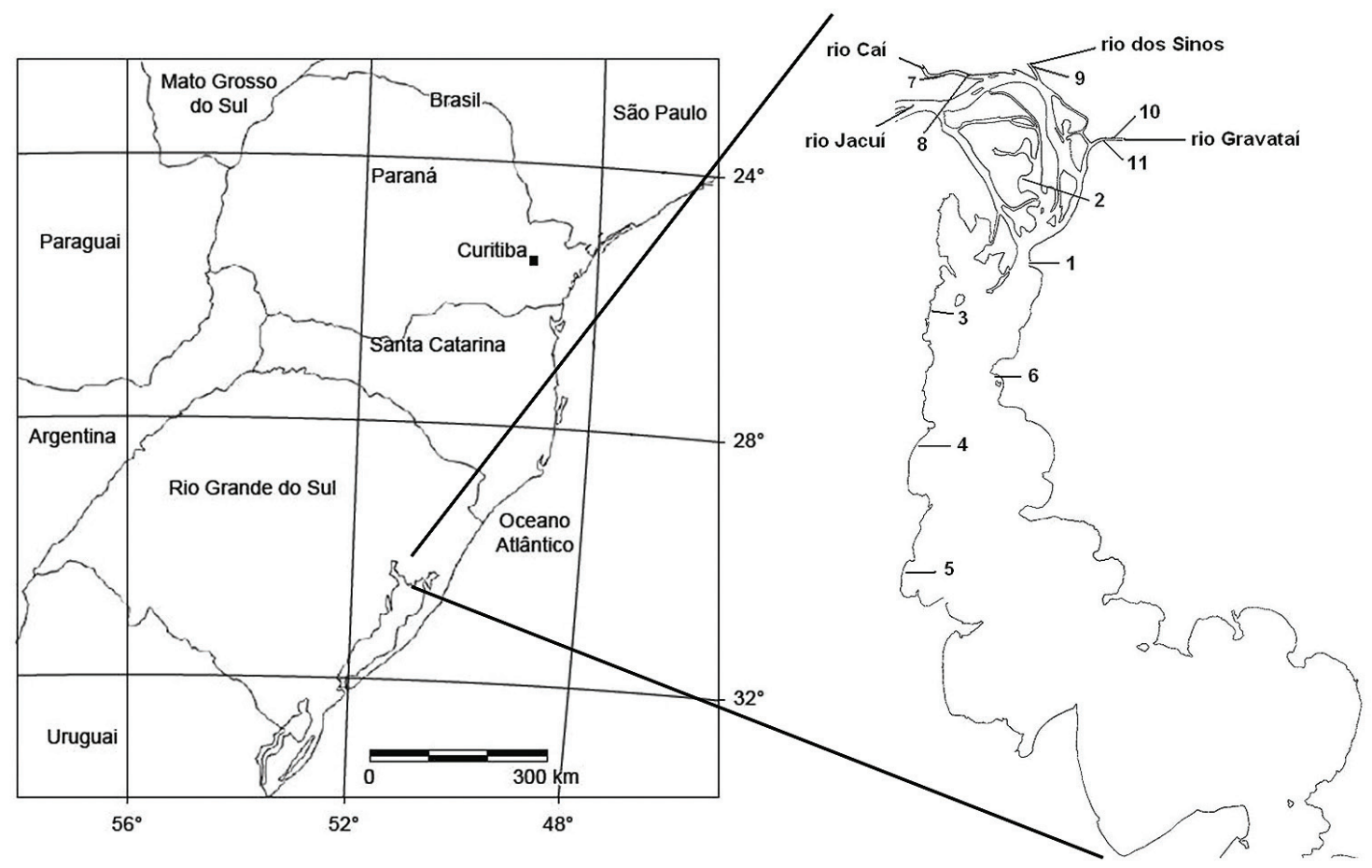

Figure 1. Map of the State of Rio Grande do Sul (Brazil) and, in detail, the Lake Guaíba basin showing the flowing rivers and sampling sites. 1 - Gasômetro, 2 - Saco da Alemoa, 3 - Foz do Celupa, 4 - Praia da Alegria, 5 - Barra do Ribeiro, 6 Praia de Ipanema, 7 - Caí, 8 - Caí-Jacuí, 9 - Sinos, 10 - GravataíRS118 and 11 - GravataíPC (Extracted from Flores-Lopes and Thomaz, 2011).

Astyanax aff. fasciatus was chosen for further analysis according to Flores-Lopes and Thomaz (2011), for being the species with the highest occurrence frequency and infection intensity. When possible, taking a random sampling as a basis, ten specimens of $A$. aff. fasciatus from each sampling spot were selected for more detailed visualisation and counting of parasites and parasitological data collection. Infected individuals of each sampling point were selected for measures of standard length (SL) and sex identification in order to verify the composition of the population. We established standard length size classes (SL) using the Rule of Sturges (Vieira, 1991).

To assess parasite distribution on the outer surface, the fish body was divided into nine regions: head, dorsal, ventral, caudal peduncle, dorsal fin, pectoral fins, pelvic fins, anal fin, caudal fin. We calculated prevalence (number of hosts infected with 1 or more individuals of a particular parasite species divided by the number of hosts examined for that parasite species), mean intensity (total number of parasites of a particular species found in a sample divided by the number of hosts infected with that parasite) and mean abundance (total number of individuals of a particular parasite species in a sample of a particular host species examined "including both infected and uninfected hosts") following Bush et al. (1997).

We calculated intensity of each infection by counting the parasites on the whole body or in each body region, the result being divided by the total number of fish per sampling site (Bush et al., 1997). Infection intensities of $>=10 \%$ are considered high (Bush et al., 1997), Quist et al. (2007). We also measured the total fish body surface area for each individual.

The simple Chi-Square test (Zar, 1999) was applied for the entire study period (two years) and for each oneyear period to assess replicability (Flores-Lopes and Thomaz, 2011).

An analysis of variance (ANOVA) Kruskal-Wallis test was used to compare infection intensities between different body regions and sampling points, and to compare total fish body surface areas. The Dunn test for multiple comparisons was used to determine the degree of significance between the different body regions studied. A UPGMA cluster analysis, using Bray Curtis distances, was used to investigate patterns of site similarities in the relative frequency of parasites (ln-transformed), was performed to verify the degree of similarity among the sampling points. Statistical analysis was performed using software Past version 1.1.

\section{Results}

Black spot disease showed low frequency in the Guaíba lake basin (2.07\%), occurring in thirteen different species. We collected 10955 specimens of Astyanax aff. fasciatus $(20.5 \%)$ of all species sampled, 5526 on the first and 5429 on the second sampling period. Among all the 
individuals analysed, 961 showed infection by black spot disease $(8.77 \%)$.

When all years were pooled, there were significant differences between F. Celupa, B. Ribeiro and Caí points (in F. Celupa point, the Chi-square test was $\mathrm{x}^{2}=184,59$ in first year and $x^{2}=20,04$ in second year, in B. Ribeiro point was $\mathrm{x}^{2}=458,34$ in first year and $\mathrm{x}^{2}=37,37$ in second year and in Caí point was $x^{2}=24,34$ in the first and $x^{2}=$ 19,13 in second year) and no incidental infection in these environments. When one-year sampling periods were analysed separately, points 3 and 5 were again significantly different (giving statistical output).

Of the 102 individuals analysed for infection intensity, 99 individuals (97\%) demonstrated some degree of infection by black spot disease with a total of 2661 parasites distributed in all body regions. The size of the specimens of $A$. aff. fasciatus ranged from 15.3 to $121.7 \mathrm{~mm}$. 80.5\% of specimens were between $36.6 \mathrm{~mm}$ to $68.6 \mathrm{~mm}$ and were therefore adults (based on standard measures of length). The sex ratio showed that $60.6 \%$ of individuals were male, $31.6 \%$ female and $7.7 \%$ young specimens which did not allow sex identification. For differences between sampling points, infection intensity was highest at Gasômetro (699), S. Alemoa (582), Sinos (338), P. Ipanema (247) and B. Ribeiro (236) and all the points had a prevalence of $100 \%$ except P. Alegria (70\%) (Table 1).

Differences between infection intensities across body areas across sampling sites are shown in Table 2. The highest infection intensities in the dorsal region were observed at P. Alegria (64.2\%, highest intensity), P. Ipanema, Caí and GravataíPC. The highest intensities in the ventral region were recorded at Gasômetro, F. Celupa, Sinos and GravataíPC. Infection intensities of the dorsal and ventral regions at GravataíPC were very similar (42.85 and 40.81 respectively), showing a slight preference for the dorsal region. The highest intensity in the ventral region was observed at Sinos (49.4\%) and the highest intensity in the dorsal region was observed in P. Alegria (64.2\%) (Table 2).

The head showed the highest intensity of infection in point Caí-Jacuí (15.4\%) and the caudal peduncle showed the highest intensity in point Sinos (12.4\%). Specifically between the fins, the caudal was the one with the highest intensity of infection, and the highest being observed in

Table 1. Number of parasites and Prevalence of infection per sampling. $\mathrm{n}=$ number of individuals; $\mathrm{n}$. $=$ number of parasites, $\mathrm{x}=$ mean, $\mathrm{SD}=$ Standard Deviation, $\mathrm{F}(\%)=$ Frequency and $\mathrm{P}(\%)=$ Prevalence of infection.

\begin{tabular}{lcccccc}
\hline \multicolumn{1}{c}{ Sampling sites } & $\mathbf{N}$ & $\mathbf{n ~ p .}$ & $\mathbf{X}$ & $\mathbf{S . ~ D . ~}$ & $\mathbf{F}$ & $\mathbf{P}(\mathbf{\%})$ \\
\hline Gasômetro & 10 & 699 & 69.9 & \pm 381.7 & 26.26 & 100 \\
S.Alemoa & 9 & 582 & 64.7 & \pm 316.0 & 21.87 & 100 \\
F. Celupa & 8 & 214 & 26.8 & \pm 113.9 & 8.04 & 100 \\
P. Alegria & 10 & 14 & 1.4 & \pm 6.4 & 0.52 & 70 \\
B. Ribeiro & 10 & 236 & 23.6 & \pm 126.7 & 8.86 & 100 \\
P. Ipanema & 10 & 247 & 24.7 & \pm 132.8 & 9.28 & 100 \\
Caí & 5 & 13 & 2.6 & \pm 5.4 & 0.48 & 100 \\
Caí-Jacuí & 10 & 168 & 16.8 & \pm 89.3 & 6.31 & 100 \\
Sinos & 10 & 338 & 33.8 & \pm 182.9 & 12.7 & 100 \\
GravataíRS118 & 10 & 101 & 10.1 & \pm 52.5 & 3.79 & 100 \\
GravataíPC & 10 & 49 & 4.9 & \pm 24.1 & 1.84 & 100 \\
& 102 & 2661 & & & & \\
\hline
\end{tabular}

Table 2. Intensity of infection by parasites that cause the black spot disease in each region of the body of Astyanax aff. fasciatus. $\mathrm{n}=$ number of individuals; $\mathrm{H}=\mathrm{Head}$; $\mathrm{D}$. $\mathrm{R} .=$ dorsal region, $\mathrm{V}$. R.= ventral region, C. $\mathrm{P} .=$ caudal peduncle, $\mathrm{D}$. F.= Dorsal fin, P. F.= Pectoral fin, Pl. F.= Pelvic fin, A. F.= Anal fin and C. F.= Caudal fin.

\begin{tabular}{|c|c|c|c|c|c|c|c|c|c|c|}
\hline \multirow{2}{*}{ Sampling sites } & \multirow{2}{*}{$\mathbf{n}$} & \multirow{2}{*}{$\mathbf{H}$} & \multirow{2}{*}{ D. $\mathbf{R}$. } & \multirow{2}{*}{ V. R. } & \multirow{2}{*}{ C. P. } & \multicolumn{5}{|c|}{ Fins } \\
\hline & & & & & & D. F. & P. F. & PI. F. & A. F. & C. F. \\
\hline Gasômetro & 10 & 8.86 & 31.47 & 40.34 & 8.86 & 1 & 0.28 & 0.28 & 0.57 & 8.29 \\
\hline S.Alemoa & 9 & 6.35 & 31.61 & 38.31 & 8.24 & 1.2 & 1.2 & 0.17 & 0 & 12.88 \\
\hline F. Celupa & 8 & 10.28 & 34.11 & 45.79 & 7.94 & 0.46 & 0 & 0 & 0 & 6.54 \\
\hline P. Alegria & 10 & 0 & 64.28 & 28.57 & 0 & 0 & 7.14 & 0 & 0 & 7.14 \\
\hline B. Ribeiro & 10 & 6.77 & 39.4 & 30.08 & 13.98 & 0 & 0.42 & 0 & 0 & 9.32 \\
\hline P. Ipanema & 10 & 6.88 & 46.15 & 31.98 & 11.33 & 0 & 0.4 & 0 & 0 & 3.23 \\
\hline Caí & 5 & 7.69 & 46.15 & 30.76 & 0 & 0 & 7.69 & 0 & 0 & 7.69 \\
\hline Caí-Jacuí & 10 & 15.47 & 35.71 & 39.28 & 5.35 & 0.59 & 0 & 0 & 0 & 3.57 \\
\hline Sinos & 10 & 10.35 & 34.61 & 49.4 & 12.42 & 0 & 0.59 & 0 & 0 & 8.87 \\
\hline GravataíRS118 & 10 & 2.97 & 25.74 & 20.79 & 2.97 & 0 & 0 & 0.99 & 0 & 0.99 \\
\hline GravataíPC & 10 & 14.28 & 42.85 & 40.81 & 0 & 0 & 0 & 0 & 0 & 2.04 \\
\hline
\end{tabular}


the S. Alemoa (12.8\%). The Gasômetro point presented infection in all regions studied in the fish body (Table 2).

Differences between body regions across the pooled sites are shown in Table 3. Ventral and dorsal regions showed the highest intensity of infection by $A$. aff. fasciatus $(38.9 \%$ and $34.7 \%$ respectively), followed by the caudal peduncle $(9.1 \%)$, head (8.6\%) and caudal fin (8.1\%) (Table 3$)$.

Infection intensities were signficantly different with respect to body area at sites Gasômetro, S. Alemoa, F. Celupa, B. Ribeiro, P. Ipanema, Cai-Jacuí, Sinos, Gravataí RS118 and Gravataí PC (ANOVA Kruskal-Wallis and Dunn test $(\mathrm{p}<0.005))$. These results are mainly a function of the combinations involving the dorsal and ventral regions of the body when compared with the pectoral, pelvic and anal regions. In other combinations, the result was not significant. At the P. Alegria point, the results of combinations were considered very significant $(p<0.005)$ and Caí point were not considered significant.

Cluster analysis suggested a division of body regions were divided into two groups. One group consisted in pelvic fins and a subgroup formed by the dorsal and anal fins. The other group consisted in the pectoral fin, with a subgroup formed by the dorsal and ventral region and the grouping formed by the caudal fin, caudal peduncle and head. The caudal fin and head form a subgroup within this grouping. The analysis shows that the ventral and dorsal regions of the body of the fish are most similar in terms of infestation degree by the parasite that causes the black spot disease.

Regarding the intensity of infection between sampling points, cluster analysis showed the formation of two groups. The first group is formed by the Gasômetro and $\mathrm{S}$. Alemoa points. The second grouping comprises the remaining points. This grouping is subdivided into two subgroups, the first one formed by the Sinos, Caí-Jacuí, F. Celupa, B. Ribeiro and P. Ipanema points. The second subgroup is formed by the P. Alegria, Caí, GravataíPC and GravataíRS118 points. The dendrogram shows high

Table 3. Total of intensity of infection by parasites that cause the black spot disease in each region of Astyanax aff. fasciatus body $\mathrm{N}=$ number of individuals; $\mathrm{H}=$ Head; D. R.= dorsal region, $\mathrm{V} . \mathrm{R} .=$ ventral region, $\mathrm{C}$. P. = caudal peduncle, D. F. = Dorsal fin, P. F. $=$ Pectoral fin, Pl. F. = Pelvic fin, A. F.= Anal fin and C. F.= Caudal fin.

\begin{tabular}{lcc}
\hline \multicolumn{1}{c}{ Region } & N & fr(\%) \\
\hline Head & 230 & 8.6 \\
Dorsal Region & 923 & 34.7 \\
Ventral Region & 1011 & 38.9 \\
Caudal Peduncle & 242 & 9.1 \\
Dorsal fin & 16 & 0.6 \\
Peitoral fin & 15 & 0.6 \\
Pelvic fin & 4 & 0.2 \\
Anal fin & 4 & 0.2 \\
Caudal fin & 216 & 8.1 \\
& 2661 & \\
\hline
\end{tabular}

similarities between the points B. Ribeiro and P. Ipanema, between the P. Alegria points and the Caí point and between the points Gasômetro and the S. Alemoa point (Figure 2).

\section{Discussion}

Questions about the effects of parasitism in fish have stimulated many researchers to focus on the parasitism effects on individuals and populations (Gilbert and Granath, 2003) and understanding the prevalence and potential effects of parasites on fish may be important for explaining patterns associated with fish population dynamics and assemblage structure (Quist et al., 2007). According to Post (1987), a common disease syndrome among freshwater fish is black spot disease and Lafferty and Morris (1996) showed that the black spots that surround metacercariae present conspicuous marks that highlight the fish body in the water environment, and may represent an efficient way to attract the attention of bird predators since the life cycle of parasites involves three hosts and adult parasites infect the digestive tract of piscivorous birds (Ondračková et al., 2004).

Flores-Lopes and Thomaz (2011), studying black spot disease in fish populations, observed that the agent causative is a Digenetic Trematode (probably Diplostomatidae family) during the metacercaria stage. They observed that the trematode settles below the stratified epithelial tissue or beneath the dense connective tissue located just below the epithelium but above the muscle and that next to the encystment lie immunological system cells and pigmented cells (chromatophores) that are responsible for the formation of dark spots.

This study found that there is no specificity between species Astyanax aff. fasciatus and black spot disease in Guaíba lake basin, contrary to observations by Teixeira-deMello and Eguren (2008) that there was a high susceptibility of $A$. aff. fasciatus to black spot disease in the Santa Lucia river basin. According to Flores-Lopes and Thomaz (2011) this species showed an elevated prevalence $(8.77 \%)$ among

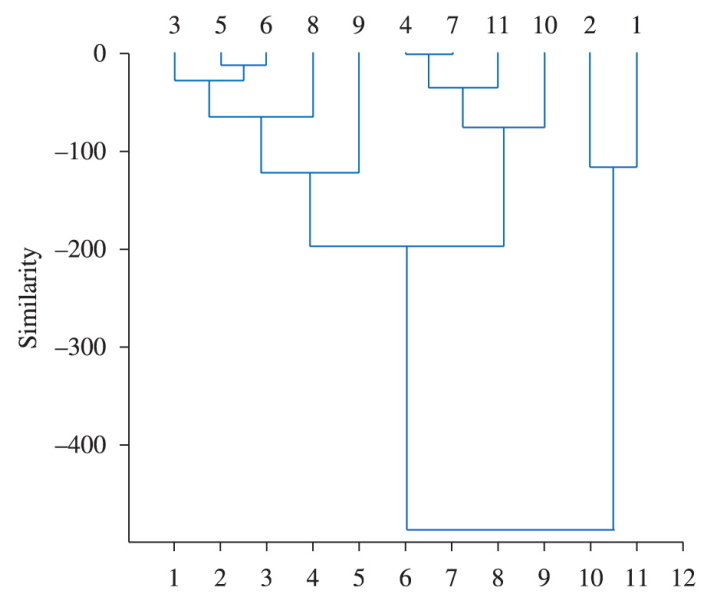

Figure 2. Dendogram of cluster analysis based on the Intensity of parasitic infection per sample site (analysis by Bray-Curtis). 
all species with the disease sampled in Guaíba Lake basin and an elevated prevalence specific for $A$. aff. fasciatus $(8 \%)$ and that the chi-square test for contingency tables has shown non-random infection in Guaíba Lake as a whole. When considering separately two sampling periods of one year, these authors reported that the results were significant for the basin as a whole and demonstrated a repetition of results in points F. Celupa and B. Ribeiro, showing non-random infection of black spot diseases for this species in these environments and a predilection of the parasites for calm waters and higher environmental quality. Their results suggested that at the time of the study, the basin had good environmental conditions for this group of parasites development, even though the intensity of infection was observed considered very low (1.79\%), which shows that the parasite is not specific for this species. Bush et al. (1997) and Quist et al. (2007) demonstrated that only values equal to or greater than $10 \%$ are considered a high rate of infection.

In this study, we observed that the prevalence in $A$. aff. fasciatus was $100 \%$, except for the P. Alegria point $(70 \%)$. On the other hand, Quist et al. (2007) observed that prevalence of infection were above $70 \%$ in four species and below $30 \%$ in one species. These authors also pointed out that although prevalence of infection in one species can be high, it can be variable among species in the same system. Ondračková et al. (2002) reported that the prevalence, abundance and intensity of disease did not show seasonal changes and/or ecological characteristics of these fish that make them more susceptible.

This study demonstrated that $80.5 \%$ of specimens of $A$. aff. fasciatus which comprised the sample were predominantly adults, whose standard length varied from $36.6 \mathrm{~mm}$ to $68.6 \mathrm{~mm}$ and $97 \%$ of specimens analysed demonstrated some intensity of infection by black spot disease. Unlike this work, Lucky (1970) reported that the causative agent of black spot disease was a pathogen observed mainly in juveniles, in which the infection can lead to an increase in mortality during the first months of life. Similarly, Cairns et al. (2005) found a significantly high rate of infection for juvenile of Oncorhynchus kisutch (Walbaum, 1792) and Ondračková et al. (2004) observed high infection on juvenile of Rutilus rutilus (Linnaeus, 1758), Scardinius erythrophthalmus (Linnaeus, 1758) and Abramis bjoerkna (Linneaus, 1758).

The fact that the Guaíba lake basin presented higher frequencies of black spot disease in more open and calmer waters (Gasômetro, S. Alemoa, Sinos, P. Ipanema, B. Ribeiro, F. Celupa and Cai-Jacuí) compared to points that had a larger impoundment of water (Gravataí RS118 and Gravataí PC), probably explains the low level of infection by black spot disease, since vegetation was reduced and there were fewer mollusc bivalves at those points. FloresLopes and Thomaz (2011) observed a predilection sites of the parasites for calm waters and improved environmental quality and these results were confirmed in this study by cluster analysis, which showed points B. Ribeiro, P. Ipanema and F. Celupa as the most similar in terms of infection by black spot disease, and P. Alegria and Caí points as the most similar among all sites. These authors also observed an elevated frequency of infection of black spot disease in $A$. aff. fasciatus in Gasômetro, S. Alemoa and Sinos points.

Studies of Ondračková et al. (2004) and Berra and Au (1978) demonstrated that normally the parasite load was higher in fish from lentic waters, compared to riverine fish where the proportion of infected fish was very low. For these authors, the frequency of parasitic infection was highest in flooded borrow pits, where infected fish were found in $74.7 \%$ of the host pools. In river fish, only $6.95 \%$ of the host pools contained infected fish, and the prevalence never exceeded 9.43\%. Ondračková et al. (2004) and Berra and $\mathrm{Au}$ (1978) showed that the host fish with the highest infection rate in his studies belong to a single subfamily, and live in slow running lowland rivers or lentic waters. For them, juveniles of these fish inhabit shallow and alluvial waters, often with vegetation on the littoral zone which is a suitable habitat for the first intermediate hosts (planorbid snails) and increases the probability of these fish infection by cercariae. For Marcogliese et al. (2001) generally lentic habitats are more likely to support a greater retention of both snails and free-swimming cercariae and higher abundances of metacercariae in fish compared to fast flowing habitats.

In this study we found a significant difference between infection intensity in the dorsal and ventral region compared to other regions of the body, with the greatest intensity of black spots being on the ventral region of the fish. This likely occurs because metacercariae exit from bivalve mollusks and fish at the ventral region and secondarily at the dorsal region, making it easier for piscivorous birds to detect the infected fish. Teixeira-de-Mello and Eguren (2008) also found significant differences in the intensity of black spot between ventral and dorsal region sections of the fish and that the greatest intensity of black spots observed was in the ventral region.

An exception to this rule was that infection intensities were very similar between the dorsal and ventral regions in the GravataíPC point, showing a slight preference for the dorsal region. This site had reduced vegetation and a small quantity of bivalve mollusks, perhaps generating the difference in pattern.

Quist et al. (2007) stated that encysted metacercariae did not appear to be concentrated in a particular body region and were found in almost all external structures, including all of the fins, the snout, head and trunk regions, and dorsal, ventral and lateral surfaces. On the other hand, Paradis and Chapleau (1994) observed that the fins are significantly more infected than the body.

An important point that should be noted is the fact that at P. Alegria, the highest percentage of infection was in the dorsal region $(64.2 \%)$ and this site had one of the lowest prevalences $(70 \%)$, suggesting that most of the parasites at this site preferred the dorsal region. This may have occurred because the site was very open with a very low frequency of bivalve mollusks. 
Several researchers have associated high black spot disease infection to growth retardation, weight loss and to the high mortality of young fish infected, which could be a regulatory factor in the host population (Harrison and Hadley, 1982; Lemly and Esch, 1985) and the disease may have important economic consequences in fish farming, the high mortality rate of fingerlings and reduced commercial value of infected fish, by the unattractive look for the consumer, as well as ornamental fish for consumption (Takemoto et al., 2004). The high percentage of infection observed in this study for the dorsal and ventral regions of $A$. aff. fasciatus showed that the fish had several black spots on its body, which makes it economically unattractive as an ornamental fish, furthermore the development of such disease may cause a significant reduction in the fish farming system production, since the specimens with the disease are not used for consumption.

Ondračková et al. (2004) observed that the standard length and body weight of more heavily infected, parasitised fish were significantly higher than in unparasitised fish. Some studies have indicated that black spot agents can result in reduced survival, growth and health of fish in natural systems (Quist et al., 2007). Harrison and Hadley (1982) pointed out that several authors have investigated the effects of the trematodes metacercariae in the health of fish hosts, however there were no consistent results. Bush et al. (2001) suggested that black spot disease is known to reduce energy reserves in infected fish, which is likely to negatively affect the immune system, and thus, facilitate secondary infections by other parasites and diseases. Lane and Morris (2000) and Herman (1990) emphasised that the stress caused by parasites lowers the tolerance of fish to environmental stressors. Paradis and Chapleau (1994) suggested that black spot disease did not influence the biology of the fish genus Phoxinus, since the condition index and the gonadosomatic index in females are not affected by the level of infection.

Besides the fact that there is a low specificity of the parasite to the $A$. aff. fasciatus species, also observed by Teixeira-de-Mello and Eguren (2008), another hypothesis for the low intensity of infection by the disease in the species may be the low water temperatures recorded in the Guaíba Lake basin in a good part of the sampling period, since the winter is harsh in this region. Flores-Lopes and Thomaz (2011) did not observe significant statistic results relating to seasonality, however they observed a greater intensity of infection at higher temperatures, and Cairns et al. (2005) observed that although other environmental factors may affect the incidence of black spot, elevated water temperature is clearly associated with higher infection rates. Ondračková et al. (2004) reported that environmental conditions such as temperature, presence of the first intermediate host or environmental characteristics represent important factors for the parasites to complete their life cycles.

Besides temperature, Galli et al. (2001) and FloresLopes and Thomaz (2011) suggested that pollution may influence the prevalence and abundance of parasites.
These authors have found that the abundance of digenetics decreases in heavily polluted areas and the occurrence of the disease was related to low environmental quality points Gasômetro, S. Alemoa, F. Celupa and Sinos.

The information obtained for these studies shows the necessity and importance of further studying the parasitic infection of fish and the effects of these parasites' action on the fish. More studies are needed so that we can understand the life cycle of these organisms, and the importance of understanding the mechanisms used and how environmental factors affect the cycle.

\section{Acknowledgements}

The author thanks MSc. Andréa Tonolli Thomas, for her help in collecting and analysing the material, Dras. Guisla Boehs and Márcia Cristina Nascimento Justo, Dr. Anthony Waldron and an anonymous reviewer for their important contribution in improving the quality of the work. The Conselho Nacional de Desenvolvimento Científico e Tecnológico provided a fellowship to FFL (proc. 476821/2003-7).

\section{References}

AMATO, sb., AMATO, jfr. and ALBRECHT, M., 2001. Metacercárias livres de diplostomídeos (Digenea, Diplostomidae) em Loricariichthys anus (Val., 1840) (Siluriformes, Loricariidae) do Estado do Rio Grande do Sul, Brasil. Parasitología al día, vol. 25, no. 1-2, p. 1-7.

BERRA, TM. and AU, RJ., 1978. Incidence of black spot disease in fishes in Cedar Fork Creek, Ohio. The Ohio Journal of Science, vol. 78 , no. 6 , p. 318-322.

BUSH, AO., FERNANDEZ, JC., ESCH, GW. and SEED, JR., 2001. Parasitism: the diversity and ecology of animal parasites. Cambridge: Cambridge University Press. 312 p.

BUSH, AO., LAFFERTY, KD., LOTZ, JM. and SHOSTAK, AW., 1997. Parasitology meets ecology on its own terms: Margolis et al. revisited. The Journal of Parasitology, vol. 83, no. 4, p. 575-583. http://dx.doi.org/10.2307/3284227. PMid:9267395

CAIRNS, MA., EBERSOLE, JL., BAKER, JP., WIGINGTON Jr., PJ., LAVIGNE, HR. and DAVIS, SM., 2005. Influence of summer stream temperatures on black spot infestation of juvenile Coho Salmon in the Oregon Coast Range. Transactions of the American Fisheries Society, vol. 134, no. 6, p. 1471-1479. http:// dx.doi.org/10.1577/T04-151.1.

DALTO, R. and MENEGHETTI, SB., 1998. Águas que se encontram. In NORONHA, LC. (Org.). Baía de todas as águas: preservação e gerenciamento ambiental na Bacia Hidrográfica do Guaíba. Porto Alegre: Secretaria da Coordenação e Planejamento do Estado do Rio Grande do Sul/Secretaria Executiva do PróGuaíba. p. 8-29.

Fundação Estadual de Proteçao Ambiental Henrique Roessler - FEPAM, 1992. Rio Grande do Sul 92: perfil ambiental e estratégias. Porto Alegre: FEPAM/FAPERGS. 20 p.

FLORES-LOPES, F. and THOMAZ, AT., 2011. Assessment of environmental quality through analysis of frequency of the black spot disease in an assemblage of fish, Guaíba Lake, RS, Brazil. Brazilian Journal of Biology, vol. 71, no. 4, p. 915-923. 
GALLI, P., CROSA, G., MARINIELLO, L., ORTIS, M. and D'AMELIO, S., 2001. Water quality as a determinant of the composition of fish parasite communities. Hydrobiologia, vol. 452, no. 1-3, p. 173-179. http://dx.doi.org/10.1023/A:1011958422446.

GILBERT, MA. and GRANATH Jr., WO., 2003. Whirling disease of salmonid fish: life cycle, biology, and disease. The Journal of Parasitology, vol. 89, no. 4, p. 658-667. http://dx.doi.org/10.1645/ GE-82R. PMid:14533670

HARRISON, EJ. and HADLEY, WF., 1982. Possible effects of black-spot disease on northern pike. Transactions of the American Fisheries Society, vol. 111, no. 1, p. 106-109. http://dx.doi. org/10.1577/1548-8659(1982)111<106:PEOBDO>2.0.CO;2.

HERMAN, RL., 1990. The role of infectious agents in fish kills. In MEYER, FP. and BARCLAY, LA. (Eds.). Field manual for the investigation of fish kills. Washington: United States Department of Interior. p. 45-56. Resource Publication, no. 117.

HOFFMAN, GL., 1967. Parasites of North American freshwater fishes. Berkeley: University California Press. 486 p.

LAFFERTY, KD. and MORRIS, AK., 1996. Altered behavior of parasitized killifish increases susceptibility to predation by bird final hosts. Ecology, vol. 77, no. 5, p. 1390-1397. http://dx.doi. org/10.2307/2265536

LANE, RL. and MORRIS, JE., 2000. Biology, prevention and effects of common grubs (digenetic trematodes) in freshwater fish. Ames: Department of Animal Ecology/Iowa State University. Technical Bulletin Series \#115.

LEMLY, AD. and ESCH, GW., 1985. Black-spot caused by Uvulifer ambloplitis (Trematoda) among juvenile centrarchids in the Piedmont area of North Carolina. Proceedings of Helminthology Society Washington, vol. 52, no. 1, p. 30-35.

LUCKY, Z., 1970. Pathological changes with posthodiplostomosis of fish fry. Acta Veterinaria, vol. 62, no. 1, p. 101-109.

MALABARBA, LR., 1989. Histórico Sistemático e Lista Comentada das Espécies de Peixes de água doce do Sistema da Laguna dos Patos. Comunicações do Museu de Ciências e Tecnologia da PUCRS. Série Zoologia, vol. 2, no. 8, p. 107-179.

MALABARBA, LR. and REIS, RE., 1987. Manual de técnicas para a preparação de coleções zoológicas. Campinas: Sociedade Brasileira de Zoologia. 14 p. Peixes, no. 36

MALABARBA, LR., PEREIRA, EHL., SILVA, JFP., BRUSCHI Jr., W. and FLORES-LOPES, F., 2004. Avaliação da qualidade da água através da freqüência de anomalias morfológicas em peixes: estudo de caso do lago Guaíba, Rio Grande do Sul, Brasil. Comunicações do Museu de Ciências e Tecnologia da PUCRS. Série Zoologia, vol. 17, no. 2, p. 97-128.

MARCOGLIESE, DJ., DUMONT, P., GENDRON, AD., MAILHOT, Y., BERGERON, E. and MCLAUGHLIN, JD., 2001. Spatial and temporal variation in abundance of Diplostomum spp. In Walleye (Stizostedion vitreum) and white suckers (Catostomus commersoni) from the St. Lawrence River. Canadian Journal of Zoology, vol. 79, no. 3, p. 355-369. http://dx.doi.org/10.1139/z00-209.

MONTEIRO, CM., AMATO, JFR. and AMATO, SB., 2007. Prosthogonimus ovatus (Rudolphi) (Digenea, Prosthogonimidae) em três espécies de aves aquáticas da Região Sul do Brasil. Revista
Brasileira de Zoologia, vol. 24, no. 1, p. 253-257. http://dx.doi. org/10.1590/S0101-81752007000100035.

ONDRAČKOVÁ, M., BARTOSOVÁ, S., VALOVÁ, Z., JURAJDA, P. and GELNAR, M., 2004. Occurrence of black-spot disease caused by metacercariae of Posthodiplostomum cuticula among juvenile fishes in water bodies in the Morava River basin. Acta Parasitologica, vol. 49, no. 3, p. 222-227.

ONDRAČKOVÁ, M., JURAJDA, P. and GELNAR, M., 2002. The distribution of Posthodiplostomum cuticula metacercariae in Young-of-the-year cyprinid fishes. Journal of Fish Biology, vol. 60, no. 5, p. 1355-1357. http://dx.doi.org/10.1111/j.1095-8649.2002. tb01731.x

OVERSTREET, RM., CURRAN, SS., POTE, LM., KING, DT., BLEND, CK. and GRATER, WD., 2002. Bolbophorus damnificus n. sp. (Digenea: Bolbophoridae) from the channel catfish Ictalurus punctatus and American white pelican Pelecanus erythrorhynchos in the USA based on life-cycle and molecular data. Systematic Parasitology, vol. 52, no. 2, p. 81-96. http:// dx.doi.org/10.1023/A:1015696622961. PMid:12075128

PARADIS, AR. and CHAPLEAU, F., 1994. Impact de la maladie des points noirs sur la biologie du complexe Phoxinus (Cyprinidae) du lac Fortune, Québec. Canadian Journal of Zoology, vol. 72, no. 9, p. 1611-1615. http://dx.doi.org/10.1139/z94-214

POST, GP., 1987. Textbook of fish health. 2nd ed. revised and expanded. Neptune City: TFH Publications. 406 p.

QUIST, MC., BOWER, MR. and HUBERT, WA., 2007. Infection by a black spot-causing species of Uvulifer and associated opercular alterations in fishes from a high-desert stream in Wyoming. Diseases of Aquatic Organisms, vol. 78, no. 2, p. 129-136. http:// dx.doi.org/10.3354/dao01875. PMid:18286809

RYCE, EKN., ZALE, AV. and MACCONNELL, E., 2004. Effects of fish age and parasite dose on the development of whirling disease in rainbow trout. Diseases of Aquatic Organisms, vol. 59, no. 3, p. 225-233. http://dx.doi.org/10.3354/dao059225. PMid:15264719

STEEDMAN, RJ., 1991. Occurence and environmental correlates of black spot disease in stream fishes near Toronto, Ontário. Transactions of the American Fisheries Society, vol. 120, no. 4, p. 494-499. http://dx.doi.org/10.1577/1548-8659(1991)120<0494:OA $\mathrm{ECOB}>2.3 . \mathrm{CO} ; 2$.

TAKEMOTO, RM., LIZAMA, MLAP., GUIDELLI, GM. and PAVANELLI, GC., 2004. Parasitas de peixes de águas continentais. In RANZANI-PAIVA, MJT., TAKEMOTO, RM. and LIZAMA, MLAP. (Orgs.). Sanidade de organismos aquáticos. São Paulo: Livraria Varela. 426 p.

TEIXEIRA DE MELLO, F. and EGUREN, G., 2008. Prevalence and intensity of black-spot disease in fish community from a subtropical stream (Santa Lucía river basin, Uruguay). Limnetica, vol. 27 , no. 2, p. $251-258$

VIEIRA, S., 1991. Introdução à bioestatística. 2nd ed. Rio de Janeiro: Campus. 294 p.

VIEIRA, EF. and RANGEL, SRS., 1988 Planicie costeira do Rio Grande do Sul: geografia fisica, vegetação e dinâmica sóciodemográfica. Porto Alegre: Sagra. 256 p.

ZAR, JH., 1999. Biostatistical analysis. 4th ed. New Jersey: Prentice-Hall. 663 p. 